\title{
Litterfall and mineral return in two cork-oak forests in northeast spain
}

\author{
A Caritat' ${ }^{1}, \mathrm{G}$ Bertoni², M Molinas ${ }^{1}, \mathrm{M}$ Oliva ${ }^{1}$, \\ A Domínguez-Planella ${ }^{1}$
}

\author{
${ }^{1}$ Cork-oak Laboratory, University of Girona, PI Hospital 6, 17071 Girona, Spain; \\ ${ }^{2}$ Laboratoire de physiologie végétale, École nationale supérieure agronomique, \\ 145, av de Muret, 31076 Toulouse, France
}

(Received 20 June 1995; accepted 12 February 1996)

\begin{abstract}
Summary - Seasonal trends in litterfall and potential mineral return were studied in two cork-oak forest sites in the northeastern Iberian peninsula. The estimated average litter production was 3.9 ${\mathrm{Mg} . h \mathrm{a}^{-1} \text {.year }}^{-1}$ for one site and $4.6{\mathrm{Mg} \cdot \mathrm{ha}^{-1} \text {.year }}^{-1}$ for the other; these figures are similar to those reported for holm-oak (Quercus ilex) forests in the same area. Seasonal litterfall patterns were typical of Mediterranean forest ecosystems. Leaves accounted for 46 to $78 \%$ of the total dry matter. Their annual weighted-average mineral composition was low in macronutrients ( $\mathrm{N} \mathrm{8-9;} \mathrm{K} \mathrm{4-5;} \mathrm{Mg} \mathrm{0.8-1.3;}$ Ca 9-10 and $\mathrm{P}$ 0.4-1 $\left.\mathrm{mg}^{-1} \mathrm{~g}^{-1}\right)$ and relatively high in micronutrients such as $\mathrm{Mn}\left(2-2.2 \mathrm{mg} \cdot \mathrm{g}^{-1}\right)$ or $\mathrm{Fe}$ $\left(0.3-0.4 \mathrm{mg}^{-1} \mathrm{~g}^{-1}\right.$. Minimum $\mathrm{N}$ and $\mathrm{P}$ concentrations were found during the growth period. Estimates of potential mineral return for an annual cycle were $\mathrm{N} 38-52, \mathrm{P} 2.1-5.2, \mathrm{~K} 20-28$, Ca 44-53 and $\mathrm{Mg}$ $5.4-5.0 \mathrm{~kg} \cdot \mathrm{ha}^{-1}$, depending on the site biomass and fertility.
\end{abstract}

cork-oak / litterfall / nutrient cycling / Mediterranean forest ecosystems / Quercus suber

Résumé - Variations saisonnières de la chute de la litière et de leur teneur en minéraux dans une forêt de chêne-liège au nord-est de l'Espagne. Les variations saisonnières de la chute de la litière et de leur teneur en minéraux ont été étudiées sur deux sites du nord-est de la péninsule ibérique. La production de litière est de 3,9 Mg.ha ${ }^{-1}$ à Quart et de 4,6 Mg.ha ${ }^{-1}$ à Sant Hilari, valeurs similaires à celles qui ont déjà été publiées pour le chêne vert dans la même région. Le type de variation observé est caractéristique des écosystèmes forestiers méditerranéens avec une chute maximale des feuilles au début de l'été. Les feuilles constituent la majeure partie de la litière et montrent de faibles teneurs en $\mathrm{N}, \mathrm{K}, \mathrm{Ca}, \mathrm{Mg}$ et spécialement en $\mathrm{P}$, et des teneurs élevées en $\mathrm{Mn}\left(2,0-2,2 \mathrm{mg} \cdot \mathrm{g}^{-1}\right)$ et en $\mathrm{Fe}$ $\left(0,3-0,4 \mathrm{mg} \cdot \mathrm{g}^{-1}\right)$. Les variations saisonnières les plus nettes sont celles des teneurs en $\mathrm{P}$ et en $\mathrm{N}$; les concentrations les plus faibles sont observées au début de l'été et sont probablement dues à la retranslocation de ces éléments. Dans l'ensemble, les valeurs observées pour le chêne-liège sont comparables à celles qui ont été publiées pour d'autres chênes méditerranéens ; les quantités de litière et d'éléments minéraux qui retournent au sol dépendent donc plus de la fertilité du sol que de l'espèce de chêne considérée.

chêne-liège / écosystème forestier méditerranéen / litière / Quercus suber / retranslocation 


\section{INTRODUCTION}

The stability of an ecosystem depends on the efficiency of nutrient recycling. In forest ecosystems, litterfall is one of the main sources of aerial mineral return to soil and, moreover, the quality and quantity of litterfall are related to primary production. In fact, the recording and study of quantitative information on litterfall is one of the best available methods for estimating changes in the function of forest ecosystems (Armentano and Woodwell, 1976).

To adapt to water-deficit conditions, trees tend to shed old leaves in order to reduce the transpiration surface. This adaptive mechanism leads to a rapid substitution of old leaves by new shoots, which exert a high photosynthetic capacity and are more efficient in water regulation (Kummerow, 1983). In the Mediterranean area, water deficit is highest in summer, but a marked variability in water supply during the growing season leads tree species to show a certain plasticity in litterfall which, in turn, affects nutrient recycling. According to Escudero and Del Arco (1987), the relatively rapid leaf abscission in Quercus suber when compared with other evergreen trees is a response to premature water stress.

Several studies have reported litterfall, nutrient content and mineral return on Mediterranean forest ecosystems, which show important interspecific differences (Kruger et al, 1983; Specht, 1988). In the Mediterranean geographic area, these facts have been investigated most often in the holm-oak forest (Quercus ilex $L$ and $Q$ rotundifolia Lamk) and in the deciduous oak forest ( $Q$ pyrenaica Willd and $Q$ faginea Lamk) (Rapp, 1971; Lossaint and Rapp, 1978; Cole and Rapp, 1981; Escarre et al, 1984; Ferrés et al, 1984; Escudero et al, 1985; Caritat and Terradas, 1990; Leonardi et al, 1992). In fact, as far as we know, studies of cork-oak litterfall are limited to those performed by our group (Oliva et al, 1992) and to those performed by Escudero and Del Arco (1987) and Escudero et al (1992), which are focused on leaf abcission and nutrient retranslocation in several tree species, the cork oak being among them.

In this paper, data are presented concerning litterfall and nutrient cycling in two selected locations that present different environmental conditions typical of those in cork-oak forests in the northeastern Iberian peninsula. A comparison is made between the values obtained in our two plots and those reported in other Mediterranean forest systems.

\section{FIELD STUDY SITES}

Two cork-oak forest plots of $400 \mathrm{~m}^{2}$, one located near the village of Quart and the other near Sant Hilari (Girona, Spain), were selected. The site in Quart $\left(41^{\circ} 51^{\prime} \mathrm{N}\right.$, $2^{\circ} 57^{\prime} \mathrm{E}$; UTM:31T DG94) is a lowland corkoak wood in the Catalonian Littoral Range subject to a xheroteric Mediterranean climate. The site in Sant Hilari $\left(41^{\circ} 53^{\prime} \mathrm{N}\right.$, $2^{\circ} 28^{\prime} E$, UTM:31T DG53) represents a highland cork-oak wood in the Catalonian Prelittoral Range, combining an axheroteric sub-Mediterranean climate with Atlantic tendencies (table I). The tree level is formed by $Q$ suber on both sites. In Quart accompanying vegetation is typical of a Mediterranean scrub-oak forest. In the undergrowth we notice Arbutus unedo, $\mathrm{Vi}$ burnum tinus and Pistacia lentiscus. In Sant Hilari the forest community consists of mixed sub-Mediterranean and Atlantic flora with a greater abundance of leguminous species. At shrub level we find Sarothamnus scoparius, Genista pilosa, Corylus avellana and Osyris alba. The trees in the Sant Hilari forest are of seedling origin and show greater biomass than in Quart (table I). On both sites soils are weakly acid but differ markedly in texture. In Sant Hilari the soil is sandy and thick, while in Quart it is silty (table II). Every 14 years both plots are subject to periodic brushwood clearance 
Table I. Physical, topographical and structural characteristics for the two forest sites in Quart and Sant Hilari (Girona, Spain).

\begin{tabular}{lcc}
\hline & \multicolumn{2}{c}{ Site } \\
\cline { 2 - 3 } & Quart & Sant Hilari \\
\hline Physical characteristics & & \\
Altitude $(\mathrm{m})$ & 240 & 850 \\
Substratum & Schists & Granodiorite \\
Aspect & $\mathrm{NW}$ & $\mathrm{SW}$ \\
Slope $(\%)$ & 25 & 35 \\
Annual precipitation $(\mathrm{mm})$ & 659 & 858 \\
Average annual temp $\left({ }^{\circ} \mathrm{C}\right)$ & $14-15$ & 11.2 \\
Forest structure & & \\
Age of tree $($ years $)$ & 50 & 75 \\
Stem diameters $(\mathrm{cm})$ & $9.3-29$ & $24-57$ \\
Average height $(\mathrm{m})$ & 11.4 & 12.4 \\
Density $\left(\mathrm{n} \cdot \mathrm{ha}^{-1}\right)$ & 875 & 575 \\
Basal area $\left(\mathrm{m}^{2} \cdot \mathrm{ha}^{-1}\right)$ & 28 & 58 \\
Biomass $\left(\mathrm{Mg}^{-1} \mathrm{ha}^{-1}\right)$ & 159 & 328 \\
\hline
\end{tabular}

and cork extraction ( $3 \mathrm{Mg}^{-h^{-1}}$ in Quart and $9 \mathrm{Mg} \cdot \mathrm{ha}^{-1}$ in Sant Hilari).

\section{METHODS}

Total soil nitrogen was analyzed by the Kjeldhal method (CMA, 1973). Soil exchangeable $\mathrm{K}$ was extracted with ammonium acetate and analyzed by flame photometry. Exchangeable $\mathrm{Ca}$ and $\mathrm{Mg}$ were determined by EDTA sodium valuation, and extractable $P$ in ammonium fluoride was analyzed by colorimetry (Jackson, 1958).

For litterfall measurements, seven $0.25 \mathrm{~m}^{2}$ conical traps were placed at random in each plot (Staaf, 1982). Collection took place monthly from July 1989 to December 1992. The samples were

Table II. General soil characteristics on the sites in Quart and Sant Hilari (Girona, Spain).

\begin{tabular}{|c|c|c|c|c|}
\hline \multirow[t]{2}{*}{ Soil characteristics } & \multicolumn{4}{|c|}{ Site } \\
\hline & \multicolumn{2}{|c|}{ Quart } & \multicolumn{2}{|c|}{ Sant Hilari } \\
\hline Depth & $0-4$ & $4-23$ & $3-17$ & $17-54$ \\
\hline Horizonts & $\mathrm{H}$ & A & A2 & B \\
\hline Gravel/stones (> $2 \mathrm{~mm}$ ) \% & 86 & 88 & 37 & 49 \\
\hline Fine hearth $(<2 \mathrm{~mm}) \%$ & 14 & 12 & 63 & 51 \\
\hline Texture & Silty loam & Silty loam & Sandy loam & Loamy sand \\
\hline $\mathrm{pH}-\mathrm{H}_{2} \mathrm{O}$ & 6.4 & 6.1 & 5.8 & 5.1 \\
\hline $\mathrm{pH}-\mathrm{KCl}$ & 6.1 & 5.2 & 4.6 & 3.8 \\
\hline $\mathrm{N} \%$ & 1.0 & 0.3 & 0.2 & 0.1 \\
\hline OM\% & 35.1 & 12.3 & 4.0 & 0.9 \\
\hline $\mathrm{C} / \mathrm{N}$ & 19.6 & 21.6 & 11.7 & 5.0 \\
\hline Exch $\mathrm{Ca}\left(\mathrm{Cmol}_{\mathrm{c}} \cdot \mathrm{kg}^{-1}\right)$ & 20.7 & 13.3 & 12.14 & 10.34 \\
\hline Exch Mg $\left(\mathrm{Cmol}_{\mathrm{c}} \cdot \mathrm{kg}^{-1}\right)$ & 8.5 & 9.5 & 7 & 5.5 \\
\hline $\operatorname{Exch~K}\left(\mathrm{Cmol}_{\mathrm{c}} \mathrm{kg}^{-9}\right)$ & 0.8 & 0.8 & 0.8 & 0.7 \\
\hline $\mathrm{P}_{2} \mathrm{O}_{5}\left(\mathrm{mg} \cdot \mathrm{kg}^{-1}\right)$ & 21.9 & 12.4 & 25.2 & 20.7 \\
\hline
\end{tabular}




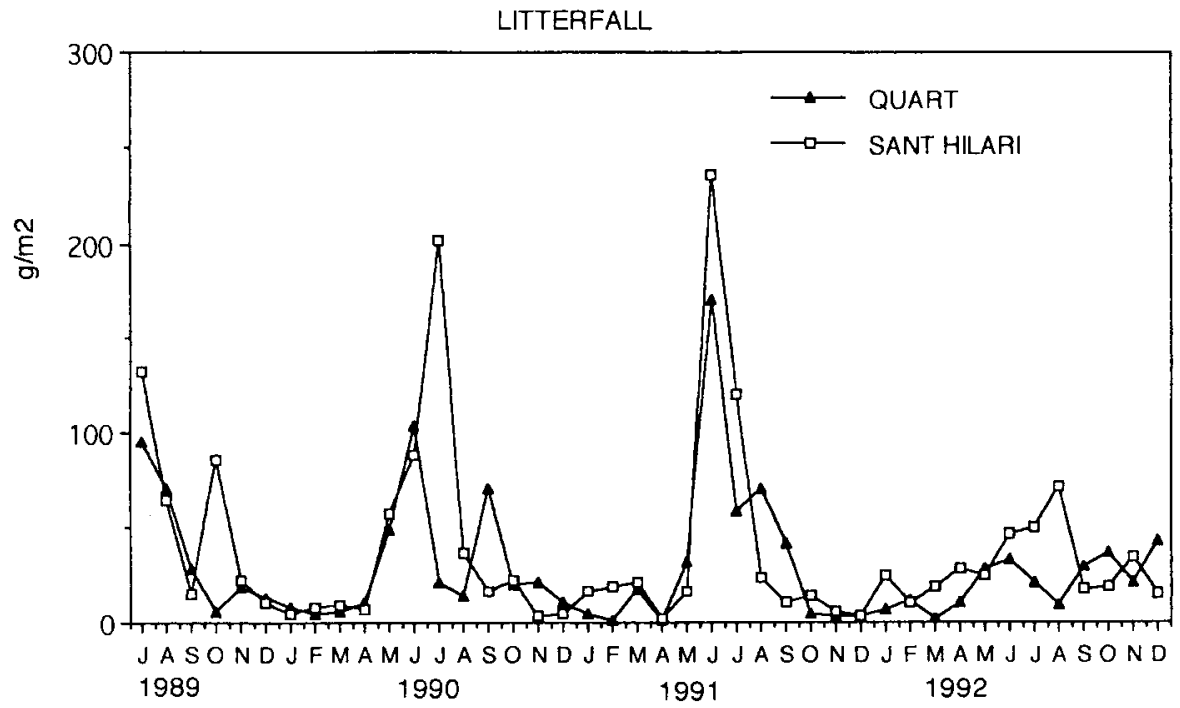

Fig 1. Seasonal patterns in the fall of litter in the cork-oak plot of Quart and Sant Hilari (Girona, Spain) from July 1989 to December 1992.

sorted into five components: leaves, twigs, male catkins, acorns and miscellaneous (including all nonidentifiable material). They were then dried at $80^{\circ} \mathrm{C}$ for $48 \mathrm{~h}$ and weighed. Samples of components with insufficient individual amounts of dry matter were combined before analysis.

Monthly and annual litterfall amount and a coefficient of variation were estimated from the monthly collected litterfall in the seven traps on each plot. The interannual variation was also estimated from the interannual standard error of the amount of dry matter recovered each year on both sites.

Chemical leaf analysis was carried out on the dry matter after grinding. Nitrogen concentration was measured by colorimetry after mineralization by sulfuric acid in the presence of the catalyzer $\mathrm{H}_{2} \mathrm{O}_{2}$ (Lindner and Harley, 1942). All the other elements were determined in a $\mathrm{HCl}$ extract of the ash obtained at $550 \mathrm{C}$, employing the method used by Bonvalet et al (1986): $\mathrm{P}$ by colorimetry, $\mathrm{K}$ by emission spectrophotometry and $\mathrm{Ca}, \mathrm{Mg}, \mathrm{Fe}, \mathrm{Cu}, \mathrm{Zn}$ and $\mathrm{Mn}$ by atomic absorption.

The mineral return was calculated as the product dry weight of litter component by element concentration. The estimated total potential annual return is the sum of the different components taken between January 1990 and Decem- ber 1990 . The annual average concentrations of the different litter components are given in the form of weighted-average for the year 1990 .

Monthly variations in the amount and mineral composition of the different litter fractions (leaves, twigs, acorns, male catkins and miscellaneous) were taken into account to estimate the average mineral content of the litterfall. Pondered estimates of the mineral content were obtained in the following way: for each fraction, annual content average is the sum of the content multiplied by the weight of the corresponding samples collected during the year, divided by the total weight of samples. Values shown correspond to the average ( \pm standard error) of the two estimates of annual averages obtained, for each litter fraction, during the period of July 1989 to June 1991.

\section{RESULTS AND DISCUSSION}

\section{Litterfall}

The fall of cork-oak litter followed the seasonal pattern of many Mediterranean forest systems with maximum litterfall occurring at the end of spring (fig 1). Total dry matter 
return-ranges recorded during the period studied were $3.6-4.3 \mathrm{Mg} \cdot \mathrm{ha}^{-1}$.year ${ }^{-1}$ in Quart and 3.9-5.1 Mg.ha- .year $^{-1}$ in Sant Hilari, with respective average annual re-

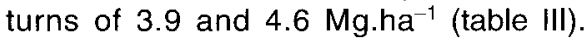
Coefficients of variation between the litterfall collected in different traps oscillated between 6 and $20 \%$.

In the cork-oak the average return of litter was similar to that recorded by Cole and Rapp (1981) and Ferrés et al (1984) in a sclerophyllous Mediterranean holm-oak forest: 3.8 and $5.3 \mathrm{Mg}^{-h^{-1}}$.year $^{-1}$, respectively. However, in comparison with the holm-oak, the cork-oak showed a relatively short abscission period, also noted by Escudero and Del Arco (1987). According to these authors and to Kummerow (1983) a short abscission period may indicate the presence of a mechanism adaptive to water stress.

The seasonal litterfall variations and the distribution of the different litterfall components showed similarities in the two sites (fig 1 and table III). Leaves were the main litter component, representing 46 to $78 \%$ of the total litterfall weight, varying according to the site and year. The main leaf-fall period occurred in June, July or at the beginning of August (fig 1). Twigs were the second litter component (12-22\% of total weight) with the maximum in summer and a smaller peak at the end of autumn or in winter. The twig fraction percentage was similar to that recorded in $Q$ pyrenaica and $Q$ rotundifolia (Escudero et al, 1985) but smaller than that recorded by Ferres et al (1984) in $Q$ ilex (26\%). Canopy structure differences found between cork- and holmoaks could explain this lower proportion of twigs in the cork-oak litterfall. The male catkin contribution was in the range of $4-8 \%$ of the total litterfall weight, with a maximum in June or July. It has been found that favourable climatic conditions lead to a second flowering period. The proportion of acorns varied greatly depending on the year, oscillating between $2 \%$ (Quart 1991) and $31 \%$ (Quart 1992). We wish to draw attention to the fact that a large fall of acorns produced in 1992 was accompanied by a low fall of leaves (table III).

\section{Mineral content of the litterfall fractions}

In the leaf fraction the mineral composition was characteristic of senescent leaves (table IV) with a relatively low content of translocable elements $(\mathrm{N}, \mathrm{K}, \mathrm{Mg}$ and especially $\mathrm{P}$ ), and high concentrations of $\mathrm{Ca}, \mathrm{Fe}$

Table III. Estimated amount of litterfall in Quart and Sant Hilari throughout three annual cycles (1990, 1991, 1992).

\begin{tabular}{lcccccc}
\hline \multicolumn{1}{c}{$g \cdot m^{-2}$} & Leaves & Twigs & Catkins & Acorns & Miscellaneous & Total \\
\hline Quart & & & & & & \\
1990 & 238 & 80 & 16 & 14 & 14 & 362 \\
1991 & 340 & 52 & 23 & 7 & 11 & 433 \\
1992 & 184 & 58 & 23 & 123 & 7 & 395 \\
$1990-1992$ & $254 \pm 46$ & $63 \pm 9$ & $21 æ 2$ & $48 \pm 38$ & $11 \pm 2$ & $396 \pm 20$ \\
Sant Hilari & & & & & & \\
1990 & 349 & 66 & 17 & 28 & 25 & 485 \\
1991 & 345 & 73 & 39 & 32 & 25 & 514 \\
1992 & 216 & 85 & 21 & 53 & 12 & 387 \\
$1990-1992$ & $303 \pm 43$ & $74 \pm 5$ & $26 \pm 6$ & $38 \pm 8$ & $21 \pm 4$ & $462 \pm 38$ \\
\hline
\end{tabular}

Mean values and standard error are provided. Litter has been divided into five separate components: leaves, twigs, male catkins, acorns and miscellaneous. 

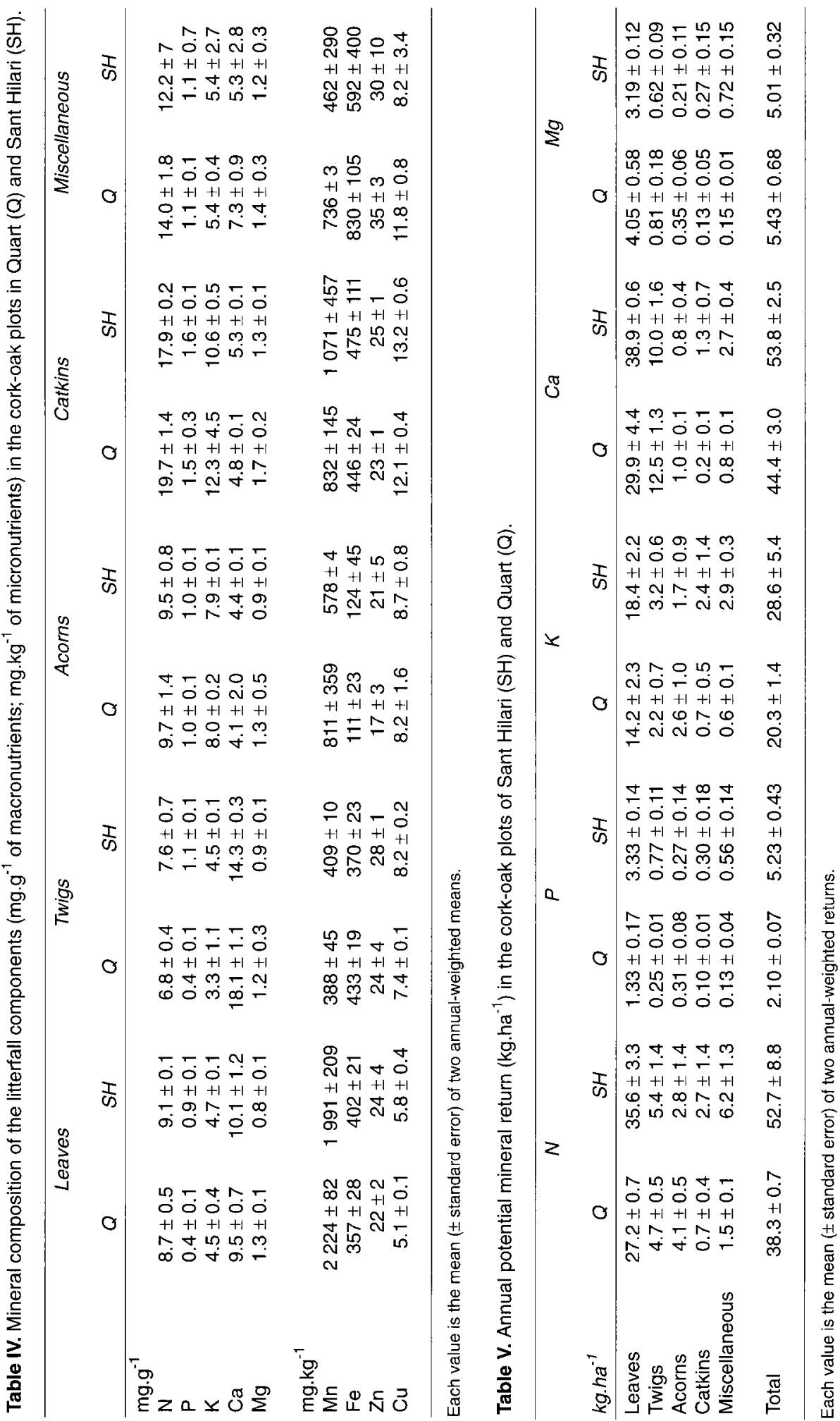

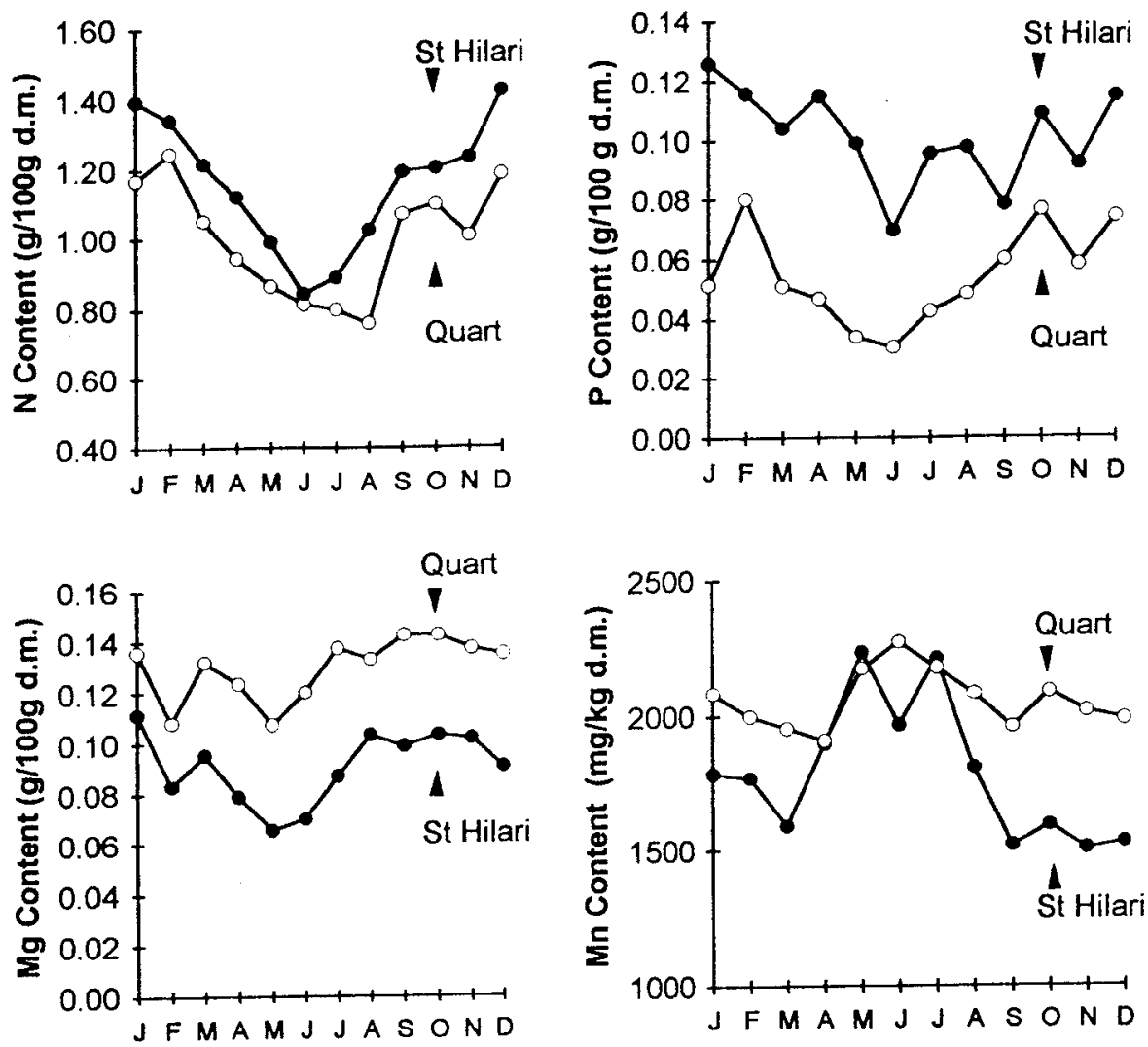

Fig 2. Average monthly mineral concentrations ( $\mathrm{g} .100 \mathrm{~g}^{-1}$ dry matter) in the leaf fraction of the litterfall in the two cork-oak forest sites.

and $\mathrm{Mn}$. The $\mathrm{N}$ concentration was very similar to that reported by Escudero et al (1985) in $Q$ rotundifolia and $Q$ pyrenaica and slightly higher than that of $Q$ ilex (Rapp, 1971; Ferrés et al, 1984). In addition, the $\mathrm{P}$ concentration was comparable with the recorded ranges of $P$ for those earlier mentioned Mediterranean oaks; and the same was true for $\mathrm{Ca}$, except for those oaks grown on a calcareous soil. The $\mathrm{K}$ concentration was close to that of $Q$ ilex ( $K$ 4-4.5 mg. ${ }^{-1}$ ) and higher than that of $Q$ rotundifolia $\left(2.9 \mathrm{mg}^{-1}\right.$ ) and $Q$ pyrenaica $\left(2.1 \mathrm{mg}^{-\mathrm{g}^{-1}}\right)$. However, $\mathrm{Mg}$ content was similar to that reported in $Q$ ilex $(\mathrm{Mg}$
$1.2 \mathrm{mg} . \mathrm{g}-1$ ) and lower than in $Q$ rotundifolia $\left(1.8 \mathrm{mg}^{-1}\right)$ and $Q$ pyrenaica $\left(2.2 \mathrm{mg}^{-1} \mathrm{~g}^{-1}\right.$ ), probably as a consequence of $\mathrm{K}-\mathrm{Mg}$ antagonism. Differences in climate and interchanging $\mathrm{K}$ and $\mathrm{Mg}$ content in the soil could explain these observed differences.

With reference to leaf fraction microelements, the $\mathrm{Cu}$ and $\mathrm{Zn}$ content was in the range of the values previously recorded in other Mediterranean oaks (Escudero et al, 1985; Caritat and Terradas, 1990); however, the $\mathrm{Fe}$ and Mn content in the cork-oak leaves was higher than that reported in Q pyrenaica (Fe $0.1 \mathrm{mg} \cdot \mathrm{g}^{-1}, \mathrm{Mn} 0.5 \mathrm{mg}^{-\mathrm{g}^{-1}}$ ), $Q$ rotundifolia(Fe $0.1{\mathrm{mg} . \mathrm{g}^{-1}}^{\mathrm{Mn}} 0.7 \mathrm{mg}^{\mathrm{g}} \mathrm{g}^{-1}$ ) 
and $Q$ ilex (Fe $0.2 \mathrm{mg} . \mathrm{g}^{-1}, \mathrm{Mn} 1 \mathrm{mg} . \mathrm{g}^{-1}$ ) by these authors. The high accumulation of $\mathrm{Mn}$ found in cork-oak leaves needs further evaluation: it may be a result of the fact that the soil is rich in available $\mathrm{Mn}$ or a peculiar feature of $Q$ suber species, given a preferential $\mathrm{Mn}$ accumulation in the old leaves.

The twig fraction composition was similar to that of leaves, except for their Ca content, which was higher, and $\mathrm{Mn}$, which was lower. The male catkin fraction was rich in $\mathrm{N}, \mathrm{P}, \mathrm{K}, \mathrm{Mg}$ and $\mathrm{Cu}$ and was poor in $\mathrm{Ca}$. The acorn component, which includes cupules and stalks, often consisted of immature acorns and showed an intermediate composition between male catkins and leaves. The miscellaneous fraction was relatively rich in macronutrients. All these litterfall components were rich in micronutrients.

\section{Seasonal evolution of mineral concentration in leaf litterfall component}

The level of $\mathrm{N}$ and $\mathrm{P}$ in the leaf litterfall component varied seasonally in both plots, but more acutely in Quart (fig 2). As a rule, the concentrations of these two elements were higher in periods of low rate fall (September-April) than in periods of high rate fall (June-August). Mg showed a similar pattern but its concentration was minimal in the period just preceding the greater fall (April-May). Mn variation also appeared to be related to the June-July leaf fall and to the production of new leaves. These variations were less marked in Quart. Seasonal fluctuations of the other elements ( $\mathrm{Ca}$, $\mathrm{Fe}, \mathrm{Cu}, \mathrm{Zn}$ ) were relatively limited.

The marked seasonal fluctuations of N, P and $\mathrm{Mg}$ content in the leaf litterfall fraction could be influenced by the age of the fallen leaves and, eventually, by the occasional winter fall of young leaves. The gradual decrease of the $\mathrm{N}, \mathrm{P}$ and $\mathrm{Mg}$ content during the period preceding the maximum leaf fall suggests that the stock of these elements in old leaves constitutes a reserve which is mobilized in the period of rapid growth. Besides, $P$ data suggest that this element could be a limiting factor in Quart.

In relation to $\mathrm{Ca}$ content, a difference between the two vegetative cycles studied was observed. In Sant Hilari, the average Ca concentration in fallen leaves was about $12 \mathrm{mg} . \mathrm{g}-1$ in the first cycle (June 1989June 1990), while it decreased to an average value of $8 \mathrm{mg} \cdot \mathrm{g}-1$ in the following period (June 1990-June 1991). In Quart, the difference between the two cycles was less marked.

\section{Annual potential mineral return}

Leaves and twigs contribute more than $76 \%$ (Sant Hilari) and $81 \%$ (Quart) to the potential mineral return of macronutrients (table V). The acorns and miscellaneous contributions were smaller in Quart than in Sant Hilari. The estimated restitution in Sant Hilari, the plot bearing the highest biomass (table I), was N 52, P 5, K 28 and $\mathrm{Ca}$ 54 , figures that in Quart did not exceed $\mathrm{N}$ 38, P 2, K 20, Ca $44 \mathrm{~kg} \mathrm{ha}^{-1}$.year $^{-1}$. The restitution in $\mathrm{Mg}$ was similar in both plots.

In Sant Hilari restitution values were somewhat higher in $\mathrm{N}$ and similar as regards the other macroelements when compared with a highland holm-oak wood located at a short distance in the Montseny range which was studied by Ferrés et al (1984) (N 35; K 22; P 4.3; Ca 48; Mg 5.9 $\mathrm{kg} \mathrm{ha}^{-1}$.year $\left.{ }^{-1}\right) . Q$ suber restitution values were also comparable with those reported by Rapp (1971) for $Q$ ilex, except for $\mathrm{Ca}$ which was higher in the holm-oaks growing in calcareous soils studied by this author.

\section{CONCLUSION}

We wish to emphasize the markedly Mediterranean character of the cork-oak forest, well-adapted to water-deficit situations and with a high internal control of a large number of nutrients, as belonging to the sclerophyllous Mediterranean systems 
(Escarré et al, 1984). This high control capacity is shown by the similar nutrient content of leaves and twigs which indicates readiness in translocation, especially for $N$ and $P$, and also by the occurrence of seasonal variations in the litterfall mineral content. In $Q$ suber, leaves shed at the time of maximum fall have lower $\mathrm{N}$ and $\mathrm{P}$ content than those shed during the winter rest period. This fact suggests that the stock of elements in old leaves constitutes a reserve which can be mobilized in periods of rapid growth and recovered during rest periods. Micronutrients show a lower retranslocation rate and tend to accumulate over a period of time as has been shown for other species.

We will note that although the plots are small and there are structural differences between sites, the observed mineral contents and returns between them are relatively similar.

Another fact that we wish to emphasize is the similarity of different Mediterranean species of Quercus as regards the mineral concentrations in their litter components and total mineral return. Only Mn concentration, reaching nearly $2000 \mathrm{mg} . \mathrm{kg}^{-1}$, is a distinctive feature of $Q$ suber in the Catalonian forests. The site fertility seems to exert a greater influence than the oak species.

In the area under study, characterized by weakly acid soils, it is worth investigating the importance of $\mathrm{P}$ as a possible limiting factor in cork-oak production.

\section{AKNOWLEDGMENTS}

Financial support was provided by the Program 'Forest' of the European Community Commission: Project MA2BCT 91-DTEE 013260.

\section{REFERENCES}

Armentano TV, Woodwell GM (1976) The production and standing crop of litter and humus in a forest exposed to chronic gamma irradiation for twelve years. Ecology 57, 360-366
Bonvalet A, Ferran J, Casassas E (1986) Análisis mineral de tejido vegetal con bajo contenido en sílice: Propuesta técnica de mineralización simplificada y de organización del procedimiento para el análisis multielemental. Oléagineux 41, 141-151.

Bru-Bistuer J (1981) Estudio pluviométrico y balance hídrico de la cuenca del Ter. Thesis, Universitat de Barcelona, Barcelona, Spain

Caritat A, Terradas J (1990) Dinàmica deis micronutrients en la caiguda i descomposició de la virosta de tres sistemes forestals del Montseny. Orsis 5 , 43-59

Caritat A, Oliva M, Molinas M (1992) Distribución de la biomasa en dos parcelas de alcornocal. Scientia gerundensis 18,131-142

CMA del INEA (1973) JM Albareda. Determinaciones analíticas en suelo. Normalización de métodos. I. $\mathrm{pH}$, materia orgánica y nitrógeno. Anal Edafología Agronómica 32, 1153-1172

Cole DW, Rapp M (1981) Elemental cycling in forest ecosystems. In: Dynamic Properties of Forest ECOsystems (DE Reichle, ed), Cambridge University Press, Cambridge, 301-409

Escarré A, Gracia C, Rodà F, Terradas J (1984) Ecología del bosque esclerófilo mediterráneo. Investigación Ciéncia (Barcelona) 95, 69-78

Escudero A, Del Arco JM (1987) Ecological significance of the phenology of leaf abscission. Oikos 49,11-14

Escudero A, Garcia B, Gómez JM, Luis E (1985) The nutrient cycling in Quercus rotundifolia and Quercus pyrenaica ecosystems ('dehesas') of Spain. Oecol Plantarum 6, 73-86

Escudero A, Del Arco JM, Sanz IC, Ayala J (1992) Effects of longevity and retranslocation efficiency and the retention time of nutrients of the leaf biomass of different woody species. Oecologia $90,80-87$

Ferres L, Rodà F, Verdú AMC, Terradas J (1984) Circulación de nutrientes en algunos ecosistemas forestales del Montseny (Barcelona). Mediterránea: Serie Biologia 7,139-166

Jackson ML (1958) Soil Chemical Analysis. PrenticeHall, Englewood Cliffs, NJ, USA

Kruger FJ, Mitchell DT, Jarvis JUM (eds) (1983) Mediterranean-type Ecosystems. The Role of Nutrients. Springer-Verlag, Heidelberg

Kummerow J (1983) Comparative phenology of Mediterranean-type plant communities. In: Mediterranean-type Ecosystems: the Role of Nutrients (FJ Kruger, DT Mitchell, JV Javis, eds), Springer-Verlag, Heidelberg, 300-317

Leonardi S, Rapp M, Denes A (1992) Organic matter distribution and fluxes within a holm oak (Quercus ilex L) stand in the Etna volcano. Vegetatio 99-100, 219-224

Lindner RC, Harley CP (1942) A rapid method for the determination of nitrogen. Science $96,565-566$

Lossaint P, Rapp M (1978) La forét méditerranéenne de chênes verts. In: Problèmes d'écologie, écosystèmes terrestres (M Lamotte, F Bourliere, eds), Masson, Paris, 129-185 
Rapp M (1971) Cycle de la matière organique et des éléments minéraux dans quelques écosystèmes méditerranéens. Éditions du CNRS, Paris, 253

Oliva M, Caritat A, Molinas M (1992) Variación estacional del desfronde en dos parcelas de alcornocal. Scientia Gerundensis 18,121-130
Staaf $H$ (1982) Plant nutrient changes in the beech leaves during senescence as influenced by site characteristics. Acta Oecol 3, 161-170

Specht RL (ed) (1988) Mediterranean-type Ecosystems. A Data Source Book. Kluwer Academic Publishers, Dordrecht, the Netherlands 